\title{
METASTATIC EYE CANCER AS A PROGNOSTIC FACTOR FOR PATIENT SURVIVAL: A REVIEW ARTICLE
}

\author{
Milana Ristić1, Sonja Cekić2,3, Nevena Zlatanović ${ }^{4}$
}

\begin{abstract}
The eye is a rare organ of metastatic disease spreading. Secondary eye tumor can be diagnosed in all structures of the eye from ocular adnexa to uvea, and optic disc.

Metastatic eye tumors originate from different primary tumor lesions such as: melanoma, squamous cellular carcinoma, lymphoid tissue tumors, breast, lungs, gastrointestinal tract, prostate, kidney, bladder. Some of these primary tumors are specific to the place of metastatic lesions. Symptoms and clinical manifestation vary according to the involvement of different structure. The diagnosis of metastatic eye tumor is connected to the poor prognosis. The treatment depends on the primary tumor lesions, part of the eye that is involved, and stage of the disease. Novel immunological, biological, and radiotherapy techniques give promising results in treatment.
\end{abstract}

Acta Medica Medianae 2021;60(3):48-55.

Key words: metastatic cancer, eye, prognosis, treatment

\footnotetext{
${ }^{1}$ University Clinical Center Niš, Clinic of Oncology, Department of Radiation Oncology, Niš, Serbia

${ }^{2}$ Universityof Niš, Faculty of Medicine, Department of

Ophthalmology, Niš, Serbia

${ }^{3}$ University Clinical Center Niš, Clinic for Eye diseases, Niš, Serbia

${ }^{4}$ Health Center, Braće Tasković Blvd., Niš, Serbia
}

Contact: Milana Ristić

74/38 Nemanjića Blvd., 18000 Niš, Serbia

E-mail: milanaristic1991@gmail.com

\section{Introduction}

The eye is a rare organ in which metastatic processes occur. Only $8-10 \%$ of all metastases are eye metastases (1). About $80 \%$ of affected persons present with a single tumor in only one eye (1). The other $20 \%$ have bilateral, multiple tumors or both $(1,2)$. Metastatic tumor to the eye may be in the ocular adnexal structures: the eyelid, lacrimal gland, conjunctiva $(1,3)$. Intrabulbar secondary tumors are detected in the uveal tract: the iris, the ciliary body, and the choroid (4-8). The optic disc can also be a site of secondary metastatic tumors $(1,9)$.

No consensus has yet been reached on a treatment strategy. Complex treatments are not recommended due to limited survival expectancy.
The most commonly used treatment is external beam radiation therapy (ERBT), most often more advanced radiation techniques due to less unwanted evacuees such as stereotaxic body radiotherapy (SBRT) and carbon ion beam radiotherapy (CIRT) are proposed (10-12). Systemic therapies targeting oncogenic drivers or immunotherapy lead to regression of choroidal metastases and improvement of visual symptoms (13-16). Transpupillary thermotherapy (TTT), enucleation and the intravitreal use of anti-VEGF factors also give a big hope for effective therapy of those conditions $(1,2,17,18)$. The aim of our study was to present the literature findings of metastatic tumors to the eye adnexa and intrabulbar tumors, prognostic factor for survival of these patients and possible treatment. The author performed a search of studies indexed in MEDLINE PubMed database using terms: metastatic cancer, eye, prognostic factor, treatment and gave the illustration of their own cases. Relevant articles were extracted and reviewed.

Eyelid

The eyelids are characterized by their complex structure, and by rich and varied pathology. They are supplied with blood through two arches which are formed by anastomoses of the lateral palpebral arteries and medial palpebral arteries. The lateral palpebral arteries and medial palpebral arteries are branches of the lacrimal artery and ophthalmic artery. The skin is thin and has more pigment cells. The skin of the eyelid contains the greatest concentration of sebaceous glands found anywhere in the body. 
Metastatic cancer of the eyelid is rare, and in multiple case series accounts for $<1 \%$ of malignant eyelid lesions (3). These patients have multiple ocular or extraocular metastatic sites. The most common is basal cell carcinoma $(80.4 \%)$, than the squamous cell carcinoma (7\%), melanoma (5.1\%), and sebaceous carcinoma $(3.3 \%)(3,19-21)$. However, of the small number of metastases to the eyelids, breast carcinoma represents the most common one $(3,21,22)$. Other distant primary tumors may originate from renal, medullary thyroid carcinoma, lung adenocarcinoma, prostate and salivary gland adenocarcinoma $(19,20,22)$. The most com-mon location is upper lid in $40 \%$ and the less common is the inner angle with $10 \%$ of all diagnosed metastatic eyelid tumors (3). Eyelid metastasis usually appears in patients with a known systemic cancer. But, it can be the first symptom of systemic cancer or the first sign of metastasis from a known malignant neoplasm (1). The management of eyelid metastases depends on the clinical features of the tumor itself: shape, location and also primary site and presence of other metastatic lesions (Figure 1a) $(1,3)$. Therapy includes excisional biopsy, EBRT, systemic chemotherapy/immunotherapy, and observation (1, 3 , 10). A small, solitary nodular lesion can be managed with excisional biopsy (Figure 1a). Survival from diagnosis can vary between 12 and 40 months, and it mostly depends on systemic primary tumor and number of lesions (Table 1) $(1,3)$. Multiple eyelid metastasis as well as metastatic lesions in other organs presented at the same time are connected to the poor prognosis.

\section{Lacrimal gland}

The lacrimal gland and lacrimal drainage system are rare places of secondary metastatic lesions. About $26-50 \%$ of all malignant tumors of lacrimal gland are metastatic $(1,23)$. Surrounding structures such as the mucosa of nasal cavity and paranasal structures during their evolution propagate to the lacrimal drainage system. In the present literature, there are case presentations of renal tumor, hepatocellular and breast tumors with metastatic progression to the lacrimal gland $(1,23,24)$. Lymphoproliferative tumor can also be diagnosed in the lacrimal gland during the progression of lymphoma, or as one of the first symptoms of lymphopoietic disorders. Lymphoproliferative lesions are softer, and mold to the globe bilaterally (23). These lesions involve both the orbital and palpebral portions of the lacrimal gland. Treatment of primary tumor is the treatment option for metastatic lesions. CIRT for head and neck cancer has already been proven a promising treatment, particularly for patients with radioresistant tumors $(12,25)$.

Prognosis of this tumor depends on primary tumor lesion and is usually poor. In the current literature, the time of survival is not precise, and it is based on few cases (Table 1).

\section{Conjunctiva}

Metastatic lesions of the conjunctiva are not common. They are typically characterized by the presence of tumor malignant cells under epithelium while the epithelium itself stays intact $(4,5,26)$. At the time of diagnosis, patients usually have distant and disseminated metastatic lesions in other organs and die within the period of one year of diagnosing conjunctival involvement (Table 1) (26).

In the present literature, colon carcinoma and cutis melanoma are described as case presentations $(4,5,26)$. In the presence of lymphoid nodular structures in conjunctiva in patients with lymphoid tumors, surgical treatment is not recommended (Figure 1b) (26). Radiotherapy and different protocol for lymphoid tumors should be used (Table 1) (1, 25).

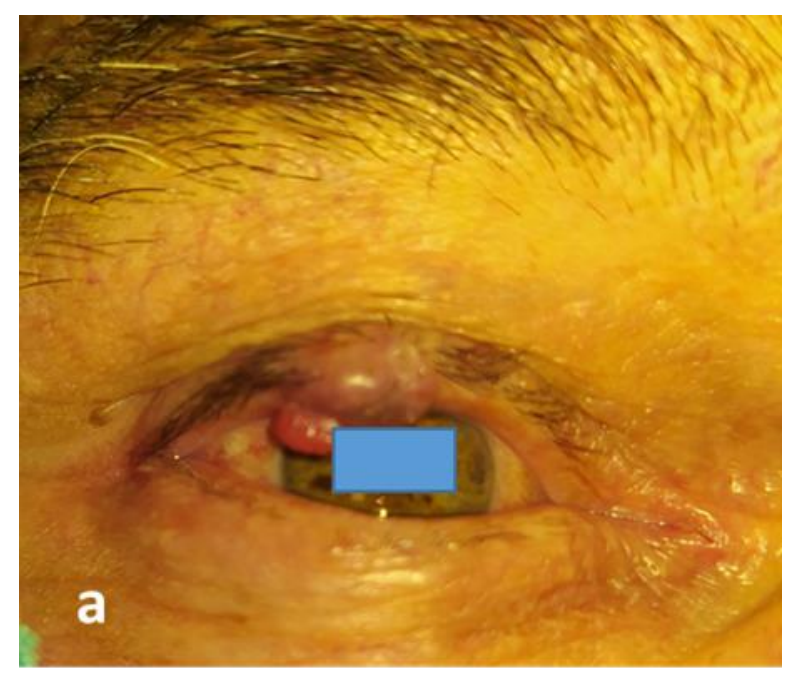

Figure 1a. Metastatic squamous cell carcinoma starting from the skin to the upper eyelid in a 78-year-old patient. Macroscopically consisted of cystic, vascular, and slightly pigmented area.

Treatment included surgical excision, $3 \mathrm{~mm}$ area, with local reconstruction. 


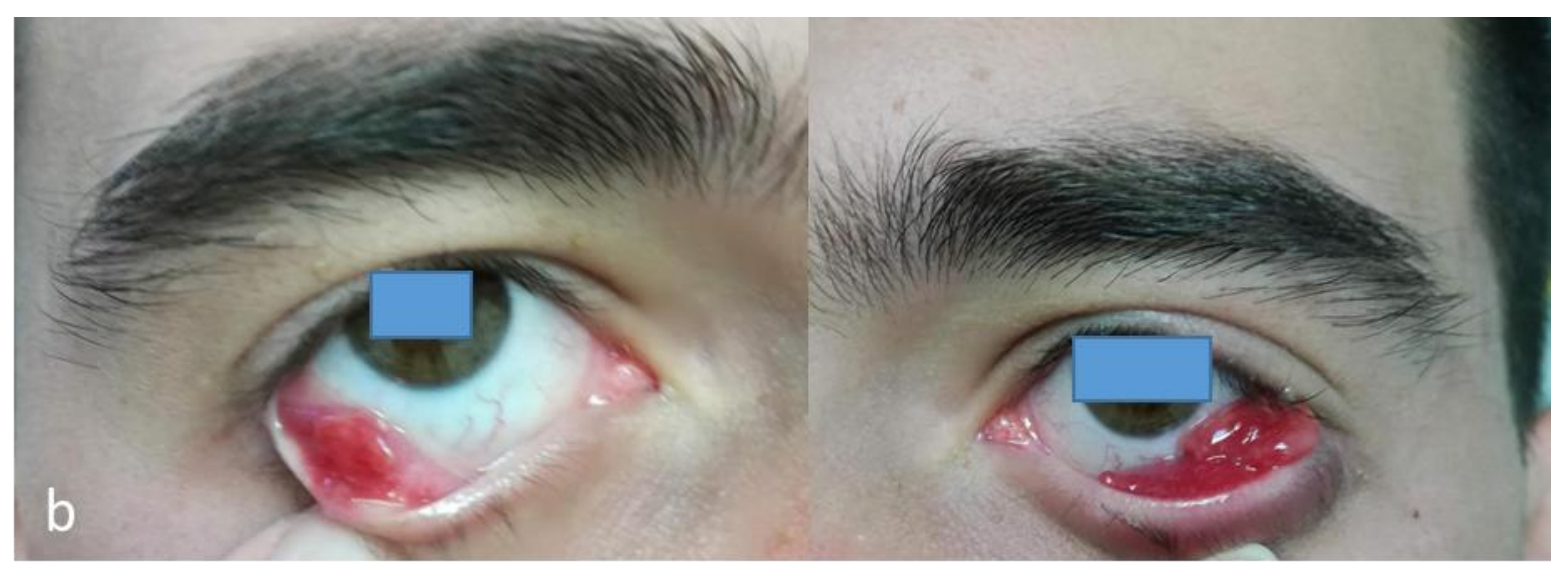

Figure 1b. Metastatic lymphoid tumor in the tarsal and bulbar conjunctiva, a 19-year-old male patient with previously diagnosed lymphoid disorder was referred to ophthalmologist for consultations. Systemic treatment of primary disease and incisional biopsy were proposed

Table 1. Primary tumor site, recommended therapy and survival in patients with metastatic cancer to the different eye structures

\begin{tabular}{|c|c|c|c|}
\hline $\begin{array}{c}\text { Site of } \\
\text { secondary } \\
\text { metastasis }\end{array}$ & Primary organ & Recommended therapy* & $\begin{array}{c}\text { Survival } \\
\text { (in months) }\end{array}$ \\
\hline Eyelid & $\begin{array}{c}\text { Basal cell carcinoma }(80.4 \%), \\
\text { Squamous cell carcinoma }(7 \%), \\
\text { Melanoma }(5.1 \%), \\
\text { Sebaceous carcinoma }(3.3 \%), \\
\text { Breast (case reports) }\end{array}$ & $\begin{array}{l}\text { Surgical excision } \\
\text { EBRT } \\
\text { Immunological }\end{array}$ & $12-40$ \\
\hline Conjunctiva & $\begin{array}{c}\text { Cutaneous melanoma, } \\
\text { Colon, } \\
\text { Lymphoid, } \\
\text { Breast (case reports) }\end{array}$ & $\begin{array}{c}\text { Surgical excision** } \\
\text { BRAF inhibitors } \\
\text { CIRT }\end{array}$ & 12 \\
\hline $\begin{array}{l}\text { Lacrimal } \\
\text { gland }\end{array}$ & $\begin{array}{c}\text { Breast, } \\
\text { Renal tumor, } \\
\text { Hepatocellular Lymphoproliferative } \\
\end{array}$ & CIRT & $24-50$ \\
\hline $\begin{array}{l}\text { Corpus } \\
\text { vitreum } \\
\text { (cavity) }\end{array}$ & $\begin{array}{l}\text { Cutaneous melanoma } \\
\text { (eyelid, sacral back) }\end{array}$ & $\begin{array}{c}\text { PPV } \\
\text { PRP } \\
\text { EBRT } \\
\text { Episcleral plaque radiation therapy } \\
\text { Enucleation }\end{array}$ & $5-14$ \\
\hline Uvea & $\begin{array}{c}\text { Breast }(37 \%-40 \%), \\
\text { Lung }(26 \%), \\
\text { Kidney }(4 \%), \\
\text { Gastrointestinal }(\mathrm{GI}) \text { tract }(4 \%), \\
\text { Cutaneous melanoma }(2 \%), \\
\text { Lung carcinoid }(2 \%), \\
\text { Prostate }(2 \%), \\
\text { Thyroid }(1 \%), \\
\text { Pancreas }(1 \%), \\
\text { Endometrial carcinoma in one patient }(1.4 \%), \\
\text { Acute myeloid leukemia in one patient }(1.4 \%), \\
\text { Unknown }(16 \%)\end{array}$ & $\begin{array}{c}\text { PPV } \\
\text { PRP } \\
\text { TTT } \\
\text { SBRT } \\
\text { Biological therapy } \\
\text { (eg. anti VEGF, epidermal GF } \\
\text { receptor tyrosine kinase inhibitors, } \\
\text { ect.) } \\
\text { Immunological }\end{array}$ & 60 (in 23\%) \\
\hline Optic disc & $\begin{array}{l}\text { Breast }(40 \%), \\
\text { Lung }(27 \%), \\
\text { Intestine }(3 \%), \\
\text { Kidney }(3 \%), \\
\text { Prostate }(3 \%), \\
\text { Unknown }\end{array}$ & EBRT & About 13 \\
\hline
\end{tabular}

*systemic therapy according to primary tumor; ** not recommended in lymphoid metastatic lesions abbreviations: EBRT-external beam radiation therapy, CIRT-carbon ion beam radiotherapy, PPV-Pars Plana Vitrectomy, PRP-Pan Retinal Photocoagulation, TTT-Trans pupillary thermotherapy SBRT-stereotaxic body radiation therapy 


\section{Corpus vitreum cavity}

Metastatic lesions of the vitreous are extremely rare. They may manifest as vitreous cells or they may be associated with one or more discrete intraocular masses $(1,27,28)$. Further, they can present with pigmented or nonpigmented cellular clumps, such as in case of cutaneous metastatic melanoma (27-31).

The route by which metastatic melanoma cells gain access to the vitreous cavity is unknown (28, 31-33). Review of the present literature shows that vitreous metastasis may be associated with retinal, ciliary body, optic disc, and iris involvement but rarely with choroidal involvement $(31,34)$. This fact points out that vitreous cells may be derived from the tissues that directly surround the vitreous cavity (34). The management of vitreous melanoma is difficult. In the case of symptomatic intraocular metastatic lesions, external beam or episcleral plaque radiation therapy is the proposed treatment (Table 1) $(1,10,28,31,34)$. Asymptomatic lesions in patients with systemic therapy should be observed. Enucleation is reserved for the case of blind, painful eye $(1,34)$.
The mean survival time of patients vary from 5 to 14 months (Table 1 ). Patients with ocular metastases from cutaneous melanoma generally have a poor prognosis (27-31).

\section{Uvea}

The uvea is the most common place of secondary eye tumor, especially the choroid $(1,2)$. This fact is due to the rich vascularization of uveal tissue itself. According to the literature, $66-71 \%$ of patients presented with knowledge of their primary cancer (6-8). The primary tumor originated in the breast (37\%-40\%), lung (26\%), kidney (4\%), gastrointestinal tract (GIT) $(4 \%)$, cutaneous melanoma $(2 \%)$, lung carcinoid $(2 \%)$, prostate $(2 \%)$, thyroid $(1 \%)$, pancreas $(1 \%)$, and unknown (16\%) (35-40). Individual choroidal lesions typically appear as relatively thin, amelanotic, round or oval choroidal masses (Figure 2a) (36-38). They are unifocal and unilateral in $80 \%$ of cases, multifocal, bilateral or both in $20 \%$ of cases (Figure 2a) $(2,41-46)$. Choroidal metastatic lesions commonly include the involvement of the optic disc and vitreous cavity (Figure 2b) $(1,2,6,47)$.

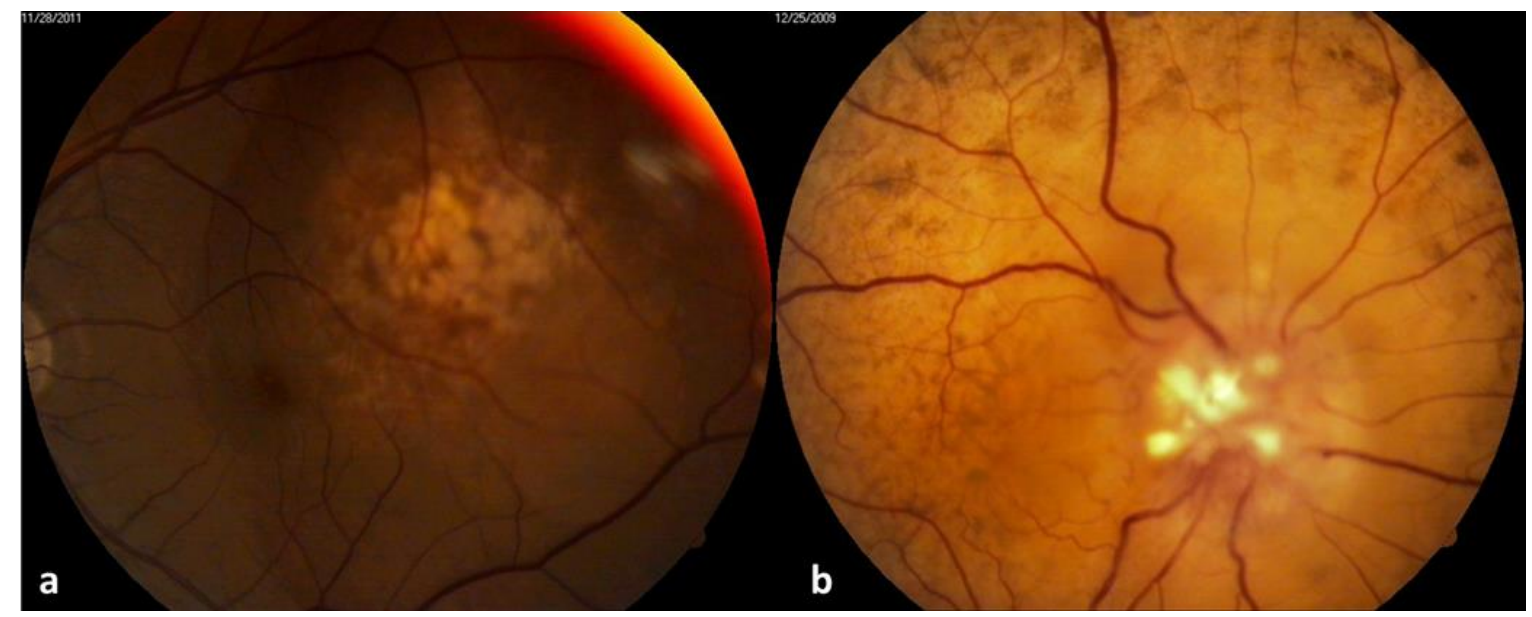

Figure 2a. Metastatic choroidal lesion in a 42-year-old man with low visual acuity, metamorphopsia, visual field defect. Choroidal metastatic lesions diagnosed as unilateral. Lung carcinoma as a primary tumor lesion diagnosed later. Treated by systemic therapy.

Figure 2b. Metastatic choroidal lesion with optic disc involvement in a 45-years-old woman with low visual acuity, metamorphopsia, visual field defect. Choroidal metastatic lesions were bilateral.

Breast carcinoma as primary tumor lesion diagnosed previously.

Treated by surgical (mastectomy) and systemic therapy (hormonal).

Systemic hormonal therapy like tamoxifen given for the primary breast and other systemic metastases may cause regression of choroidal metastasis, thereby avoiding ocular radiotherapy $(39,40)$. In the cases where chemotherapy and systemic hormonal therapy did not give results, EBRT or plaque radiotherapy and proton beam irradiation were recommended (48). More sparing irradiation treatments such as SRBT proved to be a valuable alternative for metastatic tumors to the choroid (48).

Some biological agents, like anti-VEGF, give good results in treatment of choroidal metastatic lesions $(13,18,19)$. The treatment with epidermal growth factor receptor tyrosine kinase inhibitors in patients with metastatic choroidal lesions and in patients with epidermal growth factor receptor- mutant non-small cell lung cancer gives promising results (16). Overall, life executory prognosis of uveal 
metastatic lesions is very poor with a 5-year survival in $23 \%$, the worst survival is with pancreatic metastasis, whereas the best survival is with lung carcinoid metastasis (Table 1) (49).

\section{Optic disc}

The optic disc is a site of metastatic tumors in about $5 \%$ of all intraocular metastasis $(1,9)$. The close criteria are needed for differentiation of metastatic lesions of the optic head from other causes of optic disc edema. The most common primary tumor was breast cancer (40\%), lung cancer (27\%), intestine cancer, kidney cancer and prostate cancer $(3 \%)(50-52)$. Visual acuity varied from preserved to light perception. Better visual acuity was observed in patients with smaller tumors and more eccentric location on the optic disc. The ophthalmoscopic features of the optic metastasis showed: a diffuse promination of the optic disc (84\%), the color of the tumor tissue was white $(52 \%)$ or yellow $(32 \%)$ (Figure 2c) (9). Venous stasis was noted in $64 \%$, without a complete retinal vein obstruction (9). Juxtapapillary component was present in $74 \%$ (Figure 2c) (9). Optic disc involvement was typical for adulthood. Patients usually received different treatment protocols based on primary tumor lesion (Table 1$)(1,9)$. The systemic prognosis was usually poor (Table 1).

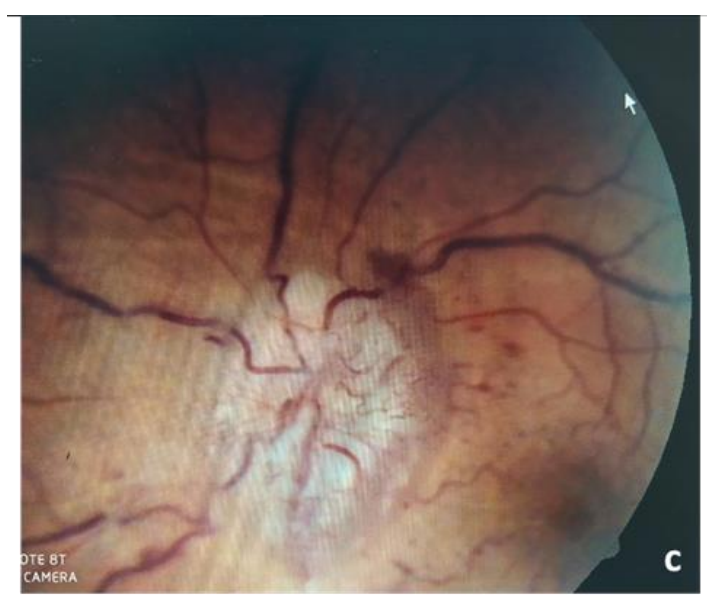

Figure 2c. . Metastatic optic disc tumor in a 42-year-old woman with low visual acuity, metamorphopsia, visual field defect. Breast carcinoma as a primary tumor lesion diagnosed previously.

\section{Conclusion}

Metastatic lesions of the eye are rare. They can be present in almost all structures of the eye. The most common site of secondary deposits is the choroid. Breast cancer is the most frequent primary tumor lesion. Sometimes the primary tumor lesion remains unknown. The treatment depends on the type of primary tumor, systemic involvement and structure of the eye that is involved. Chemotherapy, radiotherapy, and some new treatment options such as immunotherapy and biological therapy are used.

Despite early diagnosis and new treatment options, the systemic prognosis remains poor. 


\section{References}

1. Konstanidis $L$, Damato B. Intraocular metastases-A review. Asia-Pac J Ophthalmol Phila 2017;6:208-14. [CrossRef][PubMed]

2. Konstantinidis L, Rospond-Kubiak I, Zeolite I, Heimann H, Groenewald C, Coupland SE, et al. Management of patients with uveal metastases at the Liverpool Ocular Oncology Centre. $\mathrm{Br} \mathrm{J}$ Ophthalmol 2014;98:92-8. [CrossRef][PubMed]

3. Bianciotto $C$, Demirci $H$, Shields $C L$, Eagle Jr RC, Shields JA. Metastatic Tumors to the Eyelid Report of 20 Cases and Review of the Literature. Arch Ophthalmol 2009;127(8):999-1005. [CrossRef][PubMed]

4. Vora GK, Demirci H, Marr B, Mruthyunjaya P. Advances in the Management of Conjunctival Melanoma. Surv Ophthalmology 2017;62(1):26-42. [CrossRef][PubMed]

5. Shields $\mathrm{CL}$, Markowitz JS, Belinsky I, Schwartzstein $\mathrm{H}$, George NS, Lally SE. Conjunctival melanoma outcomes based on tumor origin in 382 consecutive cases. Ophthalmology 2011;118(2):389-95. [CrossRef][PubMed]

6. Camarillo C, Sánchez Ronco I, Encinas JL. Choroidal metastases. An Sist Sanit Navar 2008;31(3):127-34. [CrossRef][PubMed]

7. Wharam Jr MD, Schachat AP. Choroidal metastasis. In: Ryan SJ, ed. Retina. $4^{\text {th }}$ ed. Baltimore: ElsevierMosby; 2006:812-8. [CrossRef]

8. Shields $C L$, Shields JA, Gross NE, Schwartz GP, Lally SE. Survey of 520 eyes with uveal metastases. Ophthalmol 1997;104:1265-76. [CrossRef][PubMed]

9. Shields $J A$, Shields $C L$, Singh AD. Metastatic neoplasm in the optic disc: In the 1999 Bjerrum Lecture: Part 2. Arch Ophthalmol 2000;118:217-24. [CrossRef][PubMed]

10. Tsina EK, Lane AM, Zacks DN, Munzenrider JE,Collier JM, Gragoudas ES. Treatment of metastatic tumors of the choroid with proton beam irradiation. Ophthalmol 2005;112:337-43. [CrossRef][PubMed]

11. Marchini G, Babighian S, Tomazzoli L, Gerosa MA, Nicolato A, Bricolo A, et al. Gamma knife stereotactic radiosurgery of ocular metastases: a case report. Stereotact Funct Neurosurg 1995;64(1):67-71. [CrossRef][PubMed]

12. Hayashi $K$, Koto $M$, Ikawa $H$, Ogawa $K$, Kamada $T$. Efficacy and safety of carbon-ion radiotherapy for lacrimal gland carcinomas with extraorbital extension: a retrospective cohort study. Oncotarget 2018; 9(16): 12932-40. [CrossRef][PubMed]

13. Papageorgiou KI, Sinha A, Ioannidis AS, Neville G Davidson NG. Ocular metastases from HER2 positive breast carcinoma and the response to combination therapy with Paclitaxel and Trastuzumab:a case report. Cases Journal 2009;2:9143. [CrossRef][PubMed]

14. Mennel RG. Ocular Metastases from Breast Cancer. Clinical Breast Cancer 2001;1(4):318-9. [CrossRef][PubMed]

15. Amichetti M, Caffo O, Minatel E, Roncadin M, Valli MC, Lozza $L$, et al. Ocular metastases from breast carcinoma: A multicentric retrospective study. Oncol Rep 2000;7:761-5. [CrossRef][PubMed]

16. Bouchez C, Pluvy J, Soussi G, Nguenang M, Brosseau $S$, Tourne M. Epidermal growth factor receptor-mutant non-small cell lung Cancer and Choroidal metastases: long-term outcome and response to epidermal growth factor receptor tyrosine kinase inhibitors, BMC Cancer 2020;20:1186. [CrossRef][PubMed]

17. Rosenblatt MI, Azar DT. Anti-angiogenic therapy:prospects for treatment of ocular tumors. Semin Ophthalmol 2006;21:151-60. [CrossRef][PubMed]

18. Kuo IC, Haller JA, Reviglio VE. Intravitreal bevacizumab for a subfoveal choroidal metastasis of colorectal adenocarcinoma. Arch Ophthalmol 2008; 126: 1311-3. [CrossRef][PubMed]

19. Martina J, Fungb MA, Lina LK. Breast Cancer Metastasis Masquerading as the Great Masquerader: Sebaceous Cell Carcinoma. Case Rep Oncol 2017;10: 485-8. [CrossRef][PubMed]

20. Joseph SS, Yentz SE, Mikkilineni S, Nelson C, Kalemkerian GP. Eyelid Metastasis in Non-Small Cell Lung Cancer: Diagnosis and Management. The American Journal of Medicine 2016;128(9):169-72. [CrossRef][PubMed]

21. da Fonseca Jr NL, Lucci DLD, Cha SB, Rossetti C, Rehder JRCL. Metastatic eyelid disease associated with primary breast carcinoma: case report. Arq Bras Oftalmol 2009;72(3):390-3. [CrossRef][PubMed]

22. Bobić Radovanović $A$, Rašić $D$, Buta $M$, Džodić $R$. Breast cancer metastasis to the conjunctiva. Vojnosanit Pregl 2013;70(3):331-4. [CrossRef][PubMed]

23. von Holstein SV, Coupland SE, Briscoe D, Le Tourneau C, Heegaard S. Epithelial tumours of the lacrimal gland: a clinical, histopathological, surgical and oncological survey. Acta Ophthalmol 2013;91(3):195-206. [CrossRef][PubMed]

24. Sabatini P, Ducic Y. Bilateral Lacrimal Gland Masses: Unusual Case of Metastatic Renal Cell Carcinoma. Journal of Otolaryngology-Head \& Neck Surgery 2009; 38(1):pp E1-E2. [PubMed]

25. Dennie T. Metastatic, Her-2 Amplified Lacrimal Gland Carcinoma with Response to Lapatinib Treatment. Case Rep Oncol Med 2015;2015:262357. [CrossRef][PubMed]

26. Kiratli $H$, Shields $C L$, Shields JA, DePotter P. Metastatic tumours to the conjunctiva:report of 10 cases. $\mathrm{Br}$ J Ophthalmol 1996;80:5-8. [CrossRef][PubMed]

27. Gündüz K, Shields JA, Shields $C L$, Eagle RC. Cutaneous Melanoma Metastatic to the Vitreous Cavity. Ophthalmol 1998;705:600-5. [CrossRef][PubMed]

28. Robertson DM, Wilkinson CP, Murray JL, Gordy DD. Metastatic tumor to the retina and vitreous cavity from primary melanoma of the skin. Treatment with systemic and subconjunctival chemotherapy. Ophthalmology 1981;88:1296-301. [CrossRef][PubMed]

29. Cole EL, Zakov N, Meisler DM, Tuthill RJ, McMahon JT. Cutaneous malignant melanoma metastatic to the vitreous. Arch Ophthalmol 1986;104:98-101. [CrossRef][PubMed]

30. Best SJ, Taylor W, Allen JP. Metastatic cutaneous malignant melanoma of the vitreous and retina. Aust N Z J Ophthalmol 1990;18:397-400. [CrossRef][PubMed]

31. Zografos L, Mirimanoff RO, Angeletti CA, Frosini R, Beati D, Schalenbourg A, et al. Systemic melanoma metastatic to the retina and vitreous. Ophthalmologica 2004;218(6):424-33. [CrossRef][PubMed] 
32. Pollock SC, Awh CC, Dutton JJ. Cutaneous melanoma metastatic to the optic disc and vitreous. Arch Ophthalmol 1991;109:1352-4. CrossRef][PubMed]

33. Spraul CW, Martin DF, Hagler WS, Grossniklaus HE. Cytology of metastatic cutaneous melanoma to the vitreous and retina. Retina 1996;16:328-32. [CrossRef][PubMed]

34. Toivonen P, Makitie T, Kujala E, Kivela T. Microcirculation and Tumor-Infiltrating Macrophages in Choroidal and Ciliary Body Melanoma and Corresponding Metastases. Invest Ophthalmol \& Vis Sci 2004;45(1):1-6. [CrossRef] [PubMed]

35. Arepalli S, Kaliki SS, Shields CL. Choroidal metastases: Origin, features, and therapy. Indian Journal of Ophthalmology 2015;63(2);122-7. [CrossRef][PubMed]

36. Asteriou C, Konstantinou D, Kleontas A, Paliouras D, Samanidis G, Papadopoulou F, et al. Blurred vision due to choroidal metastasis as the first manifestation of lung cancer: A case report. World Journal of Surgical Oncology 2010;8:2. [CrossRef][PubMed]

37. Jayaram H, Asifa Shaikh A, Kheterpal S. Concomitant primary breast carcinoma and primary choroidal melanoma: a case report. Journal of Medical Case Reports 2008;2:88. [CrossRef][PubMed]

38. Piccinin MRN, JA de Almeida Jr, Aydos RD, Nogueira DC, da Silva FR. Choroid metastasis of testicular primary site: case report. Arq Bras Oftalmol 2006; 69(6):949-53. [CrossRef][PubMed]

39. Subiger L, Breton JL, Poulin J. Iris metastasis of bronchial carcinoma: case report. J Fr Ophthalmol 2008;31(5):527-35. [CrossRef][PubMed]

40. Singh A, Singh P, Sahni K, Shukla P, Shukla V, Pant KN. Non-small cell lung cancer presenting with choroidal metastasis as first sign and showing good response to chemotherapy alone: a case report. Journal of Medical Case Reports 2010;4:185. [CrossRef][PubMed]

41. de la Barquera Cordero AS, Hidalgo R A. Intravitreal Bevacizumab for Choroidal Metastasis of Lung Carcinoma; a Case Report. Journal Of Ophthalmic and Vision Research 2010;5(4);265-8. [PubMed]
42. Hadden PW, Damato BE, McKay IC. Bilateral uveal melanoma: a series of four cases. Eye 2003;17:61316. [CrossRef][PubMed]

43. Long MA, Husband JES. Features of unusal metastase from prostate cancer. The British Journal of radiology 1999;72:933-41. [CrossRef][PubMed]

44. Shields JA, Shields CL, Kiratli H, de Potter Pl. Metastatic tumors to the iris in 40 patients. Am J Ophthalmol 1995;119:422-30. [CrossRef][PubMed]

45. Soyosal HG. Metastatic tumor to the uvea in 38 eyes. Can J Ophthalmol 2007;42:832-5.

[CrossRef][PubMed]

46. Fernandes BF, Fernandes HL, Burnier MN. Choroidal mass as a presenting sing of small cell carcinoma. Can ] Ophthalmol 2006;41:605-8. [CrossRef][PubMed]

47. King BA, Rosenberger EU, Morales-Tirado VM, Wilson MW. Uveal metastases in the mid-southeastern United States: a single-institution experience. Clinical Ophthalmology 2018;12:1459-63.

[CrossRef][PubMed]

48. Mathisa $T$, Jardelc $P$, Loria $O$, Delaunaya $B$, Nguyena A, Lanzad $F$, et. al. New concepts in diagnosis and management of choroidal metastases. Progress in Retinal and Eye Research 2019;68:144-76. [CrossRef] [PubMed]

49. Welch RJ, Malik K, Mayro EL, Newman JH, Honig SE, Honig SE, et al. Uveal metastasis in 1111 patients: Interval to metastasis and overall survival based on timing of primary cancer diagnosis. Saudi Journal of Ophthalmology 2019;33:229-37. [CrossRef][PubMed]

50. Tunio MA, Al Asiri M, Riaz K, Abdulmoniem R. Optic Nerve Metastasis from Squamous Cell Carcinoma of the Uterine Cervix. Journal of the College of Physicians and Surgeons Pakistan 2015;25(9):694-5. [PubMed]

51. Fox B, Pacheco P, De Monte F. Carcinoma of the Breast Metastatic to the Optic Nerve Mimicking an Optic Nerve Sheath Meningioma: Case Report and Review of the Literature. Skull Base 2005;15(4):281289. [CrossRef][PubMed]

52. Mili Boussen I, Kamoun R, Boussen $H$, Dhiab T, Rahal $K$, Hamzaoui $A$, et al. Metastatic neoplasia in the optic nerve. Rev Neurol 2004;160:1071-4. [CrossRef][PubMed] 


\title{
METASTATSKI TUMORI OKA KAO PROGNOSTIČKI FAKTOR DUŽINE PREŽIVLJAVANJA BOLESNIKA: PREGLED LITERATURE
}

\author{
Milana Ristić ${ }^{1}$, Sonja Cekić2,3, Nevena Zlatanović4
}

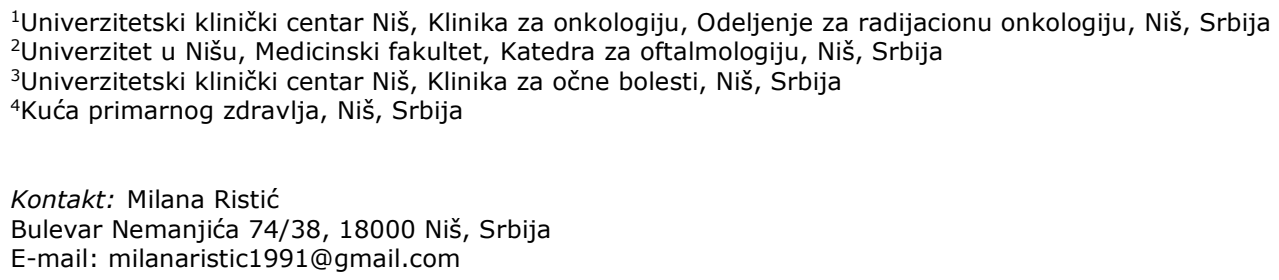

Oko je organ koji retko zahvata metastatsko širenje maligne bolesti. Sekundarni tumori oka mogu se dijagnostikovati u bilo kom delu oka, počevši od pomoćnih organa oka do sudovnjače i optičkog diska.

Metastatiski tumori oka vode poreklo od primarnih tumora, kao što su: melanom, skvamocelularni karcinom, tumori limfoidnog tkiva, dojke, pluća, digestivnog trakta, prostate, bubrega i mokraćne bešike. Neki od primarnih malignih tumora daju tipično mesto metastazarinja u oku. Simptomi i kliničke manifestacije variraju u zavisnosti od zahvaćenog dela oka. Prisustvo metastaza u oku najčešće je povezano sa lošom prognozom. Terapijski pristup zavisi od primarnog tumora, dela oka u kome je sekundarni metastatski tumor dijagnostikovan, odnosno stadijuma bolesti. Novi imunološki i biološki lekovi i nove radioterapijske tehnike daju, za sada, ohrabrujuće rezultate.

Acta Medica Medianae 2021;60(3):48-55.

Ključne reči: metastatski tumor, oko, prognoza, terapija 